\title{
Determinants of Banking Efficiency: Evidence from Egypt
}

\author{
Nader Alber ${ }^{1}$ \\ ${ }^{1}$ Faculty of Commerce, Ain Shams University, Cairo, Egypt \\ Correspondence: Nader Alber, Associate Professor, Faculty of Commerce, Ain Shams University, Cairo, Egypt. \\ Tel: 201-005-668-507. E-mail: naderalberfanous@yahoo.com
}

Received: May 18, 2015

Accepted: June 5, 2015

Online Published: July 25, 2015

doi:10.5539/ibr.v8n8p50

URL: http://dx.doi.org/10.5539/ibr.v8n8p50

\begin{abstract}
This paper aims at analyzing the effects of bank size, age and ownership on efficiency of Egyptian banks, as measured by Data Envelopment Analysis (DEA) according to CCR method. This has been conducted using Wilcoxon signed rank test, as applied on a sample of 10 banks during the period from 1984 to 2013.

Results indicate that, efficiency scores differ significantly, according to "size", "age" and "ownership" of the Egyptian banks, where small, old and private banks seem to be more efficient than big, young and public ones. Also, robustness check assures the "age" and "ownership" effects, using panel data analysis.
\end{abstract}

Keywords: bank age, bank efficiency, bank ownership, Data Envelopment Analysis (DEA), Egyptian banks, size effect

\section{Introduction}

Efficiency measurement is an aspect of firm performance that is measured with respect to an objective; it can be measured with respect to maximization of output, maximization of profits, or minimization of costs. Scale economies, scope economies, and X-efficiency are different aspects of performance. Scale and scope economies refer to selecting the appropriate outputs, while X-efficiency refers to selecting the appropriate inputs. Typically, scale economies refer to how the firm's scale of operations (its size) is related to cost. Scope economies refer to how the firm's choice of multiple product lines is related to cost (Mester, 2003, p. 2).

Data envelopment analysis (DEA) is a mathematic technique developed in operations research and management science and over the last 40 years, the field of its usage has been extensively updated. DEA is a non-parametric linear programming technique that measures the relative efficiency of a group of decision making units (DMUs) which receive multiple inputs to produce multiple outputs.

The basic idea for development of DEA method is to enable the efficiency measurement in non-profit sector (e.g., schools, hospitals, police districts, mines, air force). Later on, it was applied also in the profit sector (e.g., bank branches, production facilities) (Berger \& DeYoung, 1997; Berger \& Humphrey, 1997).

DEA, first proposed by Charnes, Cooper, and Rhodes (1978) and applied by Sherman and Gold (1985) is based on earlier work initiated by Farrell (1957). DEA has become a popular technique in bank efficiency analysis since its first application by Berger and Humphrey (1997) provides an international survey of efficient frontier analysis of financial institution performance. Maletić, Kreća, and Maletić (2013, p. 845) addresses the basics of DEA methods: CCR (Charnes, Cooper, and Rhodes), BCC (Banker, Charns, and Cooper) and AP (Andersen and Petersen).

The most basic models of DEA are CCR, BCC, Additive and SBM. CCR and BCC models are radial and aim to minimize inputs while keeping outputs at least the given output levels (input-oriented) or attempt to maximize outputs without requiring more of any of the observed input values (output-oriented). The combination of both orientations in a single model is called additive model. Additive models treat the slacks (the input excesses and output shortfalls) directly in objective function, but it doesn't have the ability to measure the depth of inefficiency by a scalar similar to $\theta^{*}$ in CCR-type models (Shafiee, Sangi, \& Ghaderi, 2013, p. 2).

DEA models that project units on the efficient frontier by reducing resources are termed input minimization models, and those that augment outputs are termed output maximization models. A DEA benchmarking model is unambiguously specified once we determine its inputs and outputs, and specify the linear programming formulation that fits the envelopment surface and projects the inefficient units on the efficient frontier (Soteriou 
\& Zenios, 1997, p. 24).

The choice of inputs and outputs is perhaps the most important task in employing DEA to measure the relative efficiency of the DMUs. Two approaches are widely used to identify a bank's inputs and outputs, the production approach (e.g., Sherman \& Gold, 1985), and the intermediation approach (e.g., Yue, 1992). Under the production approach, banks are treated as a firm to produce loans, deposits, and other assets by using labor and capital. However, banks are considered as financial intermediaries to transform deposits, purchase funds and labors into loans and other assets under the intermediation approach. More specifically, deposits are treated as an input under the production approach and an output under the intermediation approach.

Egyptian banks have expanded their activities that the growing inputs (e.g., assets, deposits, and paid interests) and outputs (e.g., loans, gained interests and net profits) reflect, during the period from 1984 to 2013. Table 1 illustrates the development of Egyptian banks' efficiency using from 1984 till 2013, as follows:

Table 1. Development of Egyptian banks' efficiency from 1984 to 2013

\begin{tabular}{|c|c|c|c|c|c|c|c|c|c|c|}
\hline Year & Bank1 & Bank2 & Bank3 & Bank4 & Bank5 & Bank6 & Bank7 & Bank8 & Bank9 & Bank10 \\
\hline 1984 & 1.0000 & 1.0000 & 1.0000 & 1.0000 & 1.0000 & 1.0000 & 1.0000 & 1.0000 & 1.0000 & 1.0000 \\
\hline 1985 & 0.0000 & 0.9908 & 08924 & 0.8709 & 1.0000 & .8015 & 0.0000 & 1.0000 & 0.0000 & 0.9626 \\
\hline 1986 & 1.0000 & 0.7821 & 0.8451 & 0.7529 & 1.0000 & 0.8185 & 0.9314 & 1.0000 & 0.9350 & 0.8918 \\
\hline 1987 & 1.0000 & 0.8231 & 0.7940 & 0.8583 & 1.0000 & 0.8347 & 0.9538 & 1.0000 & 0.8187 & 1.0000 \\
\hline 1988 & 1.0000 & 0.8982 & 0.8936 & 0.8969 & 1.0000 & 0.9961 & 1.0000 & 1.0000 & 0.8734 & 1.0000 \\
\hline 1989 & 1.0000 & 0.9398 & 0.8323 & 0.9367 & 1.0000 & 1.0000 & 0.9500 & 1.0000 & 0.9328 & 1.0000 \\
\hline 1990 & 0.9831 & 1.0000 & 0.9636 & 1.0000 & 1.0000 & 1.0000 & 0.8635 & 1.0000 & 1.0000 & 1.0000 \\
\hline 1991 & 0.8494 & 1.0000 & 1.0000 & 0.8329 & 1.0000 & 0.9879 & 0.8894 & 1.0000 & 1.0000 & 1.0000 \\
\hline 1992 & 0.8276 & 0.9448 & 0.9136 & 0.7079 & 1.0000 & 1.0000 & 0.9540 & 1.0000 & 0.9754 & 0.8319 \\
\hline 1993 & 0.5683 & 0.8766 & 0.7369 & 0.8105 & 1.0000 & 0.8660 & 1.0000 & 1.0000 & 0.7206 & 0.7754 \\
\hline 1994 & 0.8808 & 0.6868 & 0.7065 & 0.8362 & 1.0000 & 0.9477 & 0.8974 & 1.0000 & 0.5817 & 0.8777 \\
\hline 1995 & 0.7935 & 0.7123 & 0.7665 & 0.8144 & 1.0000 & 0.9510 & 0.9755 & 0.9214 & 1.0000 & 0.8715 \\
\hline 1996 & 0.8001 & 0.8192 & 0.9035 & 0.9755 & 1.0000 & 1.0000 & 1.0000 & 1.0000 & 0.9445 & 0.9133 \\
\hline 1997 & 0.8682 & 0.9130 & 0.9524 & 0.9424 & 1.0000 & 1.0000 & 1.0000 & 1.0000 & 0.9268 & 0.9357 \\
\hline 1998 & 0.6320 & 0.7684 & 0.7587 & 0.6821 & 1.0000 & 0.8697 & 1.0000 & 1.0000 & 0.9436 & 0.8284 \\
\hline 1999 & 0.7175 & 0.8727 & 0.9275 & 0.8001 & 1.0000 & 1.0000 & 1.0000 & 1.0000 & 0.7939 & 0.8770 \\
\hline 2000 & 0.7494 & 0.8922 & 0.9674 & 0.9212 & 1.0000 & 0.9785 & 1.0000 & 1.0000 & 1.0000 & 0.8383 \\
\hline 2001 & 0.7095 & 0.8081 & 0.9275 & 0.9042 & 1.0000 & 0.9702 & 1.0000 & 0.9210 & 1.0000 & 1.0000 \\
\hline 2002 & 0.7961 & 0.8204 & 1.0000 & 0.8674 & 1.0000 & 1.0000 & 1.0000 & 0.8546 & 1.0000 & 0.9008 \\
\hline 2003 & 0.7365 & 0.7568 & 0.9655 & 0.8670 & 1.0000 & 1.0000 & 0.9621 & 0.7793 & 1.0000 & 1.0000 \\
\hline 2004 & 0.7181 & 0.6457 & 0.9370 & 0.8501 & 1.0000 & 1.0000 & 0.8882 & 0.7678 & 1.0000 & 1.0000 \\
\hline 2005 & 0.6212 & 0.7946 & 0.9622 & 0.8219 & 1.0000 & 1.0000 & 0.9931 & 0.9506 & 1.0000 & 1.0000 \\
\hline 2006 & 0.7569 & 1.0000 & 0.9544 & 0.7941 & 1.0000 & 1.0000 & 1.0000 & 0.9236 & 1.0000 & 1.0000 \\
\hline 2007 & 0.8265 & 1.0000 & 0.7571 & 1.0000 & 1.0000 & 0.9897 & 1.0000 & 1.0000 & 1.0000 & 1.0000 \\
\hline 2008 & 0.6320 & 1.0000 & 0.8546 & 0.8206 & 1.0000 & 0.8765 & 0.8935 & 0.9985 & 1.0000 & 1.0000 \\
\hline 2009 & 0.7074 & 1.0000 & 0.7910 & 0.8349 & 1.0000 & 0.7898 & 0.9648 & 0.9228 & 1.0000 & 1.0000 \\
\hline 2010 & 0.7345 & 1.0000 & 0.8331 & 1.0000 & 1.0000 & 0.8107 & 0.9101 & 0.8493 & 1.0000 & 1.0000 \\
\hline 2011 & 0.7591 & 1.0000 & 0.9339 & 0.8812 & 1.0000 & 0.8534 & 1.0000 & 0.9630 & 0.9396 & 0.8964 \\
\hline 2012 & 0.7484 & 1.0000 & 0.9633 & 0.8692 & 1.0000 & 0.7586 & 1.0000 & 1.0000 & 0.9063 & 1.0000 \\
\hline 2013 & 0.7995 & 1.0000 & 1.0000 & 0.9307 & 1.0000 & 0.8179 & 1.0000 & 0.9317 & 0.9970 & 0.9083 \\
\hline
\end{tabular}

Source: calculated by the researcher using DEA according to CCR method. 
In brief, this study tries to answer these three main questions:

- Does "bank size" affect its efficiency?

- Does "bank age" affect "banking efficiency"?

- Does "ownership type" affect "banking efficiency"?

This paper addresses a main question about determinants of "banking efficiency", as measured DEA technique using CCR method. Determinants of performance, to be examined, are variables related to "bank size", "bank age" and "ownership type".

The paper is arranged as follows: after this introduction, section 2 reviews research literature that has concerned with "banking efficiency" and "banking characteristics" that include size, age and ownership type. Section 3 explains how to measure research variables and illustrates how to test the hypotheses. Section 4 is for empirical work, presenting results, discussing how these results answer research questions using Wilcoxon Signed Rank Test and providing a robustness check using step-wise regression technique. Section 5 summarizes the paper and provides remarks about conclusions.

\section{Literature Review}

This section presents some of previous work, which has been conducted in the field of "banking efficiency" and "banking characteristics" that may affect banking efficiency.

Regarding "banking efficiency", Aly et al. (1990) uses CCR model to evaluate the technical, scale and allocative efficiencies of 322 USA banks in 1986. The number of full-time staff, fixed asset, capital and loanable fund are chosen as inputs; while real estate loan, commercial and industrial loan, consumer loan, miscellaneous loan, and current deposit are chosen as outputs.

Andersen and Petersen (1993) propose ranking model that shows how much the unit can "get worse" but still be efficient. Superefficient units are those with efficiency of over 100\%, the most efficient is the one which is highest ranked, while the units with efficiency less than $100 \%$ are inefficient and therefore ranked lower.

Soteriou and Zenios (1997) have indicated that analyzing banks' efficiency should include branches, service quality, operations, and profitability, simultaneously. The authors develop a framework for combining strategic benchmarking with efficiency benchmarking of the services offered by bank branches. They use 3 DEA models: an operational efficiency model, a quality efficiency model and a profitability efficiency model. Empirical results indicate that superior insights can be obtained by analyzing operations, service quality, and profitability simultaneously than the information obtained from benchmarking studies of these 3 dimensions separately.

Berger and Humphrey (1997) documents 130 studies of financial institution efficiency, as applied on 21 countries, from multiple time periods, and from various types of institutions, including banks, credit unions, and insurance companies. Results suggest that progress has been made on efficiency measurement rather than that has been made in explaining the differences in performance (i.e., profitability or efficiency) across institutions. Athanassopoulos et al. (2000) examines 47 branches of the Commercial Bank of Greece and uses the DEA results to implement the proposed changes in the bank performance measurement system.

Milind (2003) carried out the banks efficiency analysis in India on the basis of two models. Model A inputs are: interest expenses, non-interest expenses, and outputs: net interest income, net non-interest income, and model B inputs are: deposits, employees, and outputs: net loans, non-interest income). Fries and Taci (2004) compares the performance of 289 banks in 15 post-communist countries, using an intermediate approach. The results show that foreign banks are more competitive and have better results in cost efficiency than domestic banks.

Efficiency of Canadian banks has been investigated by Avkiran (2006) and Wu et al. (2006). Avkiran (2006) applies DEA using a sample of 24 Canadian foreign bank subsidiaries in year 2000. The outputs include loans, securities and non-interest income, while inputs include deposits, non-interest expenses and equity multiplier. Wu et al. (2006) integrates the DEA and neural networks (NNs) to examine the relative branch's efficiency of a big Canadian bank. The authors observe 142 banks in Canada, and monitor the number of employees and costs for input indicators; while for output they monitor deposits, income and bank loans.

Sakar (2006) in Turkey analyzes 11 banks and monitors input: branch numbers, employees per branch, assets, loans, deposits, and outputs: ROA, ROE, interest income and non-interest income (assets). Hassan and Sanchez (2007) used DEA to estimate the efficiency of Latin American banks during the period from 1996 to 2003. Results indicate that most of the sources of inefficiencies are regulatory rather than technical. This means that bank managers do not choose the correct (optimal) input and output mix, because they are not forced to do so by the environmental conditions (either government regulations or market conditions). 
Moh'd Al-Jarrah (2007) uses DEA approach to investigate cost efficiency levels of banks operating in Jordan, Egypt, Saudi Arabia and Bahrain over 1992-2000. The estimated cost efficiency is further decomposed into technical and allocative efficiency at both variable and constant return to scale. Later on, the technical efficiency is further decomposed into pure technical and scale efficiency. Results show that cost efficiency scores range from 50 to $70 \%$ with some variations in scores depending on bank's size and geographical locations. Avkiran (2009) applied non-oriented network slacks-based measure in domestic commercial banks of United Arab Emirates (UAE), using non-oriented, non-radial SBM modeling.

Alber (2011) considers the effects of banking expansion on profit efficiency of the Saudi banks. This has been conducted using a sample of 6 commercial banks (out of 11), and covering the period from 1998 to 2007. Profit efficiency has been measured using the ratio of actual profitability to the best one, which a similar bank can realize. Tests indicated that we could accept hypotheses regarding the effects of "availability of phone banking", "number of ATMs" and "number of branches" on profit efficiency of Saudi banks.

Maletić, Kreća, and Maletić (2013) uses DEA technique in case of measuring operation efficiency of the banking sector in Serbia, which currently has 33 banks. Input and output indicators differ according to the used models A and B. According to Model A, inputs include interest expenses and non-interest expenses, while outputs include interest income and net non-interest income. According to Model B, inputs include deposits and employees, while outputs include loans and operating income.

Shafiee, Sangi, and Ghaderi (2013) evaluates the efficiency of an Iranian bank using dynamic SBM model in DEA during three consecutive terms considering net profit as a good link and loan losses as a bad link. Each branch in each term expends money on labor salaries and operating expense as inputs to produce loans as output. In each term some loans become non-performing, because of unable borrowers to make full or even partial payment. Dynamic SBM efficiency is compared with its static efficiency to check the validity of described model. In addition, input-bad link excesses and output-good link shortfalls (slacks) are analyzed and further suggestions to the management are provided.

Thayaparan and Pratheepan (2014) focuses on total factor productivity growth and its decomposition of commercial banks in Sri Lanka, as applied on two state banks and four private banks over the period 2009-2012. By using DEA, total factor productivity and its components are measured in terms of efficiency change, technical efficiency change, pure efficiency change and scale change. Interest income and loans are considered as outputs and deposits, total assets, number of staff and interest expenses are considered as inputs. Results indicate that, all six banks operate averagely at $87.2 \%$ of overall efficiency and that less performance is achieved due to the less progress in technical change than efficiency change. The overall results conclude that private banks are more efficient than state banks.

Concerning with banking characteristics, Carvallo and Kasman (2005) indicates that very small and very large banks are significantly more inefficient than large banks, as applied on 481 Latin American and Caribbean banks over the years from 1995 to 1999 using a stochastic frontier model (SFA). Besides, Anis and Sami (2012) shows that small and medium-sized banks are more efficient than large ones, private banks are more efficient than public ones and foreign banks are more efficient than domestic ones, as applied on 17 Tunisian banks over the period 1997-2006 using a parametric approach stochastic (SFA).

Alber (2014) aims at analyzing the effects of "size", "seasonality" and "attitude to risk" on the performance Egyptian banks. This has been conducted using a sample of 10 banks, and covering the period from the first quarter 2003 to the fourth quarter 2011. Results indicate that, hypotheses regarding the significance of differences between performance indicators, according to "size", "seasonality" and "attitude to risk" on the performance Egyptian banks could be accepted.

Comparing with previous work, the current study:

- Tries to investigate its determinants, while the most of previous work focuses on only efficiency assessment. Berger and Humphrey (1997) addresses that progress has been made on efficiency measurement rather than that has been made in explaining efficiency differences.

- Combines size effect, age and ownership, while the most of previous work concerns with only one or two of these aspects.

\section{Data Description and Hypotheses Developing}

Required data regarding bank efficiency, size, age and ownership indicators could be shown as follows: 
Table 2. Variables representing bank efficiency, size, age and ownership

\begin{tabular}{lll}
\hline Variable & Calculation & Sign \\
\hline Banking Efficiency & Measured by DEA technique according to CCR approach. & CCR \\
Bank Size $^{(1)}$ & $=0$ for small banks and $=1$ for big banks & SIZ \\
Bank Age $^{(2)}$ & $=0$ for young banks and $=1$ for old banks & AGE \\
Bank Ownership & $=0$ for public banks and $=1$ for private banks & OWN \\
\hline
\end{tabular}

This paper aims at testing the following three hypotheses:

- There is no significant effect of "bank size" on its efficiency.

- There is no significant effect of "bank age" on its efficiency.

- There is no significant effect of "bank ownership" on its efficiency.

Regarding the first hypothesis, the null hypothesis $\mathrm{H}_{0}$ states that, for each mean efficiency indicator $\mu_{\mathrm{CCR}}$ :

$$
\mu_{\mathrm{CCR}-\mathrm{SMALL}}=\mu_{\mathrm{CCR}-\mathrm{BIG}}
$$

The alternative hypothesis $\mathrm{H}_{\mathrm{a}}$ could be shown as:

$$
\mu_{\mathrm{CCR}-\mathrm{SMALL}} \neq \mu_{\mathrm{CCR}-\mathrm{BIG}}
$$

Regarding the second hypothesis, the null hypothesis $\mathrm{H}_{0}$ states that, for each mean efficiency indicator $\mu_{\mathrm{CCR}}$ :

$$
\mu_{\mathrm{CCR}-\mathrm{YOUNG}}=\mu_{\mathrm{CCR}-\mathrm{OLD}}
$$

The alternative hypothesis $\mathrm{H}_{\mathrm{a}}$ could be shown as:

$$
\mu_{\mathrm{CCR}-\mathrm{YOUNG}} \neq \mu_{\mathrm{CCR}-\mathrm{OLD}}
$$

Regarding the third hypothesis, the null hypothesis $\mathrm{H}_{0}$ states that, for each mean efficiency indicator $\mu_{\mathrm{CCR}}$ :

$$
\mu_{\text {CCR-PUBLIC }}=\mu_{\text {CCR-PRIVATE }}
$$

The alternative hypothesis Ha could be shown as:

$$
\mu_{\text {CCR- PUBLIC }} \neq \mu_{\text {CCR- PRIVATE }}
$$

Robustness checks test the significance of differences between CCRs according banks size, age and ownership could be shown, as follows:

$$
C C R=\alpha+\beta_{1} S I Z+\beta_{2} A G E+\beta_{3} O W N
$$

Regarding each of banks' characteristics, the null hypothesis $\mathrm{H}_{0}$ could be shown as:

$$
\left.\beta_{n}=0 \text { (where } n=1,2,3\right)
$$

The alternative hypothesis $\mathrm{H} 1$ could be shown as:

$$
\beta_{n} \neq 0(\text { where } n=1,2,3)
$$

\section{Results of Empirical Study}

The following table illustrates the means of bank efficiency scores according to size, age and ownership for a sample of 10 Egyptian banks during the period from 1984 to 2013:

Table 3. Means of bank efficiency according to size, age and ownership

\begin{tabular}{lcccccc}
\hline Year & $\mathbf{S I Z}_{\mathbf{S}}$ & $\mathbf{S I Z}_{\mathbf{B}}$ & $\mathbf{A G E}_{\mathbf{Y}}$ & $\mathbf{A G E}_{\mathbf{O}}$ & SEA $_{\mathbf{P}}$ & SEA $_{\mathbf{V}}$ \\
\hline 1984 & 1.0000 & 1.0000 & 1.0000 & 1.0000 & 1.0000 & 1.0000 \\
1985 & 0.9906 & 0.9259 & 0.9508 & 0.9528 & 0.9385 & 0.9607 \\
1986 & 0.9396 & 0.8664 & 0.8760 & 0.9153 & 0.8450 & 0.9294 \\
1987 & 0.9431 & 0.8850 & 0.8951 & 0.9214 & 0.8688 & 0.9345 \\
1988 & 0.9683 & 0.9475 & 0.9378 & 0.9739 & 0.9222 & 0.9782 \\
1989 & 0.9707 & 0.9515 & 0.9418 & 0.9766 & 0.9272 & 0.9805 \\
1990 & 0.9659 & 0.9911 & 0.9893 & 0.9727 & 0.9867 & 0.9773 \\
\hline
\end{tabular}




\begin{tabular}{|c|c|c|c|c|c|c|}
\hline 1991 & 0.9723 & 0.9450 & 0.9365 & 0.9754 & 0.9206 & 0.9795 \\
\hline 1992 & 0.9403 & 0.8990 & 0.8788 & 0.9523 & 0.8485 & 0.9602 \\
\hline 1993 & 0.8740 & 0.8097 & 0.7985 & 0.8724 & 0.7481 & 0.8937 \\
\hline 1994 & 0.8392 & 0.8430 & 0.8221 & 0.8609 & 0.7776 & 0.8841 \\
\hline 1995 & 0.9421 & 0.8396 & 0.8173 & 0.9439 & 0.7717 & 0.9532 \\
\hline 1996 & 0.9645 & 0.9164 & 0.8996 & 0.9716 & 0.8745 & 0.9763 \\
\hline 1997 & 0.9656 & 0.9460 & 0.9352 & 0.9725 & 0.9190 & 0.9771 \\
\hline 1998 & 0.9430 & 0.7851 & 0.7682 & 0.9283 & 0.7103 & 0.9403 \\
\hline 1999 & 0.9177 & 0.8863 & 0.8636 & 0.9342 & 0.8294 & 0.9452 \\
\hline 2000 & 0.9596 & 0.9181 & 0.9060 & 0.9634 & 0.8825 & 0.9695 \\
\hline 2001 & 0.9802 & 0.8866 & 0.8698 & 0.9782 & 0.8373 & 0.9819 \\
\hline 2002 & 0.9389 & 0.9140 & 0.8968 & 0.9511 & 0.8710 & 0.9592 \\
\hline 2003 & 0.9353 & 0.8877 & 0.8652 & 0.9483 & 0.8315 & 0.9569 \\
\hline 2004 & 0.9140 & 0.8585 & 0.8302 & 0.9312 & 0.7877 & 0.9427 \\
\hline 2005 & 0.9859 & 0.8666 & 0.8400 & 0.9887 & 0.8000 & 0.9906 \\
\hline 2006 & 0.9809 & 0.9176 & 0.9011 & 0.9847 & 0.8763 & 0.9873 \\
\hline 2007 & 1.0000 & 0.9289 & 0.9167 & 0.9979 & 0.8959 & 0.9983 \\
\hline 2008 & 0.9730 & 0.8639 & 0.8614 & 0.9537 & 0.8268 & 0.9614 \\
\hline 2009 & 0.9719 & 0.8539 & 0.8667 & 0.9355 & 0.8333 & 0.9462 \\
\hline 2010 & 0.9399 & 0.8964 & 0.9135 & 0.9140 & 0.8919 & 0.9284 \\
\hline 2011 & 0.9497 & 0.9046 & 0.9148 & 0.9305 & 0.8935 & 0.9421 \\
\hline 2012 & 0.9766 & 0.8899 & 0.9162 & 0.9330 & 0.8952 & 0.9441 \\
\hline 2013 & 0.9592 & 0.9247 & 0.9460 & 0.9310 & 0.9326 & 0.9425 \\
\hline
\end{tabular}

Source: collected and processed by the researcher using DEA according to CCR method.

The previous table shows the means of bank efficiency according to size, age and ownership as a whole that don't indicate these means according to categories of bank "size", "age" or "ownership". The following table illustrates the means CCRs according to banks' characteristics, for small-sized banks (SIZ $\mathrm{S}_{\mathrm{S}}$, big-sized banks $\left(\mathrm{SIZ}_{\mathrm{B}}\right)$, young banks $\left(\mathrm{AGE}_{\mathrm{Y}}\right)$ and old banks $\left(\mathrm{AGE}_{\mathrm{O}}\right)$. In addition, it shows the means of these characteristics, for public banks $\left(\mathrm{OWN}_{\mathrm{P}}\right)$ and private banks $\left(\mathrm{OWN}_{\mathrm{V}}\right)$, as follows:

Table 4. Descriptive statistics of efficiency indicators

\begin{tabular}{lccccccc}
\hline Variables & Sign & N & Min. & Max. & Mean & Std. Dev. & Kolmogorov-Smirnov Z \\
\hline Efficiency (Small Banks) & SIZ $_{\mathrm{S}}$ & 30 & .84 & 1.00 & .9534 & .03450 & 0.934 \\
Efficiency (Big Banks) & SIZ $_{\mathrm{B}}$ & 30 & .79 & 1.00 & .8983 & .04807 & 0.499 \\
Efficiency (Young Banks) & $\mathrm{AGE}_{\mathrm{Y}}$ & 30 & .77 & 1.00 & .8918 & .05368 & 0.498 \\
Efficiency (Old Banks) & $\mathrm{AGE}_{\mathrm{O}}$ & 30 & .86 & 1.00 & .9488 & .03296 & 0.666 \\
Efficiency (Public Banks) & $\mathrm{OWN}_{\mathrm{P}}$ & 30 & .71 & 1.00 & .8648 & .06710 & 0.496 \\
Efficiency (Private Banks) & OWN $_{\mathrm{V}}$ & 30 & .88 & 1.00 & .9574 & .02747 & 0.664 \\
\hline
\end{tabular}

Source: collected and processed by the researcher.

Efficiency score of using DEA according to CCR method is $95.34 \%$ for small banks, while it's $89.83 \%$ for big ones. Efficiency scores are $89.18 \%$ and $94.88 \%$ for young and old banks respectively. Besides, they are $86.48 \%$ and $95.74 \%$ for public and private banks respectively. However, these differences don't indicate significance. Kolmogorov-Smirnov test shows that variables are not normally distributed. So, Wilcoxon signed rank test (as a non-parametric test) is conducted to check the significance of these differences, as follows: 
Table 5. Testing hypotheses using Wilcoxon signed rank test

\begin{tabular}{lcc}
\hline Pair of Variables & Wilcoxon Signed Rank Test Z & Sig. \\
\hline Efficiency of Small vs. Big banks & -4.552 & 0.000 \\
Efficiency of Young vs. Old banks & -4.530 & 0.000 \\
Efficiency of Public vs. Private banks & -4.681 & 0.000 \\
\hline
\end{tabular}

Source: collected and processed by the researcher.

Testing Hypotheses using Wilcoxon signed rank test shows, at p-value of 0.01 , that there's a significant differences between banks' efficiencies, as follows:

- According to bank size, results indicate that efficiency scores of small banks are significantly different from those of big ones. Small banks seem to be more efficient than big ones.

- According to bank age, results indicate that efficiency scores of old banks are significantly different from those of young ones. Old banks seem to be more efficient than young ones.

- According to bank ownership, results indicate that efficiency scores of private banks are significantly different from those of public ones. Private banks seem to be more efficient than public ones.

Testing Hypotheses using Wilcoxon signed rank test shows, at p-value of 0.01 , indicates that the null hypothesis is rejected, for the second and third hypotheses. This means that the alternative one could be accepted showing significant difference in Egyptian banks' efficiencies, due to their size, age and ownership.

To check the robustness of these results, step-wise regression analysis has been conducted and provides the following results:

Table 6. Determinants of bank efficiency

\begin{tabular}{ccccccc}
\hline Variables entered & $\boldsymbol{\alpha}$ & Size & Age & Own & F & $\mathbf{R}^{2}$ \\
\hline \multirow{2}{*}{ Own } & $\mathbf{0 . 8 6 5}$ & --- & -- & $\mathbf{0 . 0 9 3}$ & 79.818 & 0.211 \\
& $(0.008)^{* * *}$ & & & $(0.010)^{* * *}$ & & $(0.0879)^{* * *}$ \\
Own & $\mathbf{0 . 8 1 4}$ & -- & $\mathbf{0 . 0 5 1}$ & $\mathbf{0 . 1 3 5}$ & 45.277 & 0.234 \\
Age & $(0.019)^{* * *}$ & & $(0.017)^{* * *}$ & $(0.018)^{* * *}$ & & $(0.0868)^{* * *}$ \\
\hline
\end{tabular}

Note. Each cell contains the estimated parameters, with std error between brackets, where * denotes p-value of $10 \%$, ** denotes $5 \%$ and $* * *$ denotes $1 \%$.

Table 6 indicates that "bank ownership" may explain $21.1 \%$ of efficiency score at p-value of $1 \%$ and when adding "bank age", $\mathrm{R}^{2}$ becomes $23.4 \%$. This means that:

- Regarding bank size: Robustness check does not support the results obtained by conducting Wilcoxon signed rank test. Literature indicates that this point still needs to be more elaborated. Moh'd Al-Jarrah (2007) shows that bank's size affects its cost efficiency scores. Besides, Carvallo and Kasman (2005) indicates that on average, very small and very large banks are significantly more inefficient than large banks. In addition, Anis and Sami (2012) sows that small and medium-sized banks are more efficient than large ones.

- Regarding bank age: Robustness check supports its effect, as it adds to the explanatory power. Really, $\mathrm{R}^{2}$ has been increased only by $2.3 \%$ (from $21.1 \%$ to $23.4 \%$ ), but the effect seems to be significant and robust.

- Regarding bank ownership: Robustness check supports the results obtained by conducting Wilcoxon signed rank test. In addition, literature assures this effect, where Fries and Taci (2004) and Anis and Sami (2012) indicate that foreign banks are more efficient than domestic ones. Besides, Thayaparan and Pratheepan (2014) concludes that private banks are more efficient than state ones. Bank ownership explains $21.1 \%$ of efficiency scores and this could be more elaborated by analyzing private banks characteristics that may enhance efficiency. Further research may investigate their competitive advantages in areas of risk management, systemic risk and financial stability. 


\section{Summary and Concluded Remarks}

This paper aims at analyzing the effects of bank size, age and ownership on efficiency of Egyptian banks, as measured by Data Envelopment Analysis (DEA) according to CCR method. This has been conducted using Wilcoxon signed rank test, as applied on a sample of 10 banks during the period from 1984 to 2013.

Results indicate that, efficiency scores differ significantly, according to "size", "age" and "ownership" of the Egyptian banks, where small, old and private banks seem to be more efficient than big, young and public ones. Also, robustness check assures the "age" and "ownership" effects, using panel data analysis.

Bank ownership explains $21.1 \%$ of efficiency scores and this could be more elaborated by analyzing private banks characteristics that may enhance efficiency. Further research may investigate their competitive advantages in areas of risk management, systemic risk and financial stability.

\section{References}

Alber. (2011). The effect of banking expansion on profit efficiency of Saudi banks. $2^{\text {nd. }}$ International Conference on Business and Economic Research, Langkawi, Malaysia, March14-16, 2011.

Alber. (2014). Size effect, seasonality, attitude to risk and performance of Egyptian banks. International Business Research, 7(1), 92-93.

Aly, H., Grabowski, R., Pasurka, C., \& Rangan, N. (1990). Technical scale and allocative efficiencies in US banking: An empirical investigation. Review of Economics and Statistics, 72(2), 211-218. http://dx.doi.org/10.2307/2109710

Andersen, P., \& Petersen, N. (1993). Procedure for ranking efficient units in data envelopment analysis. Management Science, 39(10), 1261-1264. http://dx.doi.org/10.1287/mnsc.39.10.1261

Anis, O., \& Sami, R. (2012). Financial liberalization (FL), environment variables and cost efficiency of Tunisian banking system. Journal of Applied Finance and Banking, 2(5), 1-25.

Athanassopoulos, A., \& Giokas, D. (2000). The use of data envelopment analysis in banking institutions: Evidence from the commercial bank of Greece. Interfaces, 30, 81-95. http://dx.doi.org/10.1287/inte.30.2.81.11678

Avkiran, N. (2006). Using DEA in benchmarking. JASSA, 2(2). Retrieved from http://www.finsia.com/docs/default.../2_2006_dea_benchmarking.pdf?sfvrsn

Avkiran, N. (2009). Opening the black box of efficiency analysis: An illustration with UAE banks. Omega, 37, 930-941. http://dx.doi.org/10.1016/j.omega.2008.08.001

Banker, R., Charnes, A., \& Cooper, W. (1984). Some models for estimating technical and scale inefficiencies in data envelopment analysis. Management Science, 30(9), 1078-1092. http://dx.doi.org/10.1287/mnsc.30.9.1078

Berger, A., \& DeYoung, R. (1997). Problem loans and cost efficiency in commercial banks. Journal of Banking and Finance, 21, 849-870. http://dx.doi.org/10.1016/S0378-4266(97)00003-4

Berger, A., \& Humphrey, D. (1992). Measurement and efficiency issues in commercial banking. In Output Measurement in the Service Sectors (pp. 245-300). University of Chicago Press.

Berger, A., \& Humphrey, D. (1997). Efficiency of financial institutions: International survey and directions for future research. Journal of Operational Research, 98, 175-212. http://dx.doi.org/10.1016/S0377-2217(96)00342-6

Carvallo, O., \& Kasman, A. (2005). Cost efficiency in the Latin American and Caribbean banking systems. Journal of International Financial Markets Institution and Money, 15, 55-72. http://dx.doi.org/10.1016/j.intfin.2004.02.002

Charnes, A., Cooper, V., \& Rhodes, E. (1978). Measuring the efficiency of decision making units. European Journal of Operational Research, 2, 429-444. http://dx.doi.org/10.1016/0377-2217(78)90138-8

Farrell, M. (1957). The measurement of productive efficiency. Journal of the Royal Statistical Society, Series A, General, 120(Part 3), 253-281. http://dx.doi.org/10.2307/2343100

Fries, S., \& Taci, A. (2004). Cost efficiency of banks in transition: Evidence from 289 banks in 15 post-communist countries. Journal of Banking and Finance, 29, 55-81. http://dx.doi.org/10.1016/j.jbankfin.2004.06.016 
Hassan, K., \& Sanchez, B. (2007). Efficiency determinants and dynamic efficiency changes in Latin American banking industries. http://dx.doi.org/10.2139/ssrn.1087045

Kuo, H., \& Wang, L. (2007). Operating performance by the development of efficiency measurement based on fuzzy DEA. In Second International Conference on Innovative Computing, Information and Control, ICICIC'07 (pp. 196-196). http://dx.doi.org/10.1109/ICICIC.2007.423

Maletić, R., Kreća, M., \& Maletić, P. (2013). Application of DEA methodology in measuring efficiency in the banking sector. Economics of Agriculture, 60(4), 843-855.

Mester, L. (2003). Applying efficiency measurement techniques to central banks. FRB of Philadelphia Working Paper \# 03-13. http://dx.doi.org/10.2139/ssrn.572442

Milind, S. (2003). Efficiency of banks in a developing economy: The case of India. European Journal of Operational Research, 148, 662-671. http://dx.doi.org/10.1016/S0377-2217(02)00471-X

Moh'd Al-Jarrah, I. (2007). The use of DEA in measuring efficiency in Arabian banking. Banks and Bank Systems Journal, 2(4), 21-30.

Mohamed, M. (2006). Modelling the efficiency of GCC banks: A data envelopment analysis approach. International Journal of Productivity and Performance Management, 56(7), 623-643.

Şakar, B. (2006). A study on efficiency and productivity of Turkish banks in Istanbul stock exchange using malmquist DEA. Journal of American Academy of Business, 8(2), 145-155.

Shafiee, M., Sangi, M., \& Ghaderi, M. (2013). Bank performance evaluation using dynamic DEA: A slacks-based measure approach. Journal of Data Envelopment Analysis and Decision Science, 1-12. http://dx.doi.org/10.5899/2013/dea-00026

Sherman, H., \& Gold, F. (1985). Bank branch operating efficiency: Evaluation with data envelopment analysis. Journal of Banking and Finance, 9, 297-316. http://dx.doi.org/10.1016/0378-4266(85)90025-1

Soteriou, A., \& Zenios, S. (1997). Efficiency, profitability and quality of banking services. Working Papers \# 97-28, Center for Financial Institutions, Wharton School, University of Pennsylvania.

Thayaparan, A., \& Pratheepan, T. (2014). Evaluating total factor productivity growth of commercial banks in Sri Lanka: An application of malmquist index. Journal of Management Research, 6(3), 58-68. http://dx.doi.org/10.5296/jmr.v6i3.5513

Vujčić, B., \& Jemrić, I. (2001). Efficiency of banks in transition: A DEA approach. Dubrovnik, Draft version. Retrieved from http://www.hnb.hr/dub-konf/7.../vujcic-efficiency-of-banks-dea-approach.pdf

Wu, D., Yang, Z., \& Liang, L. (2006). Using DEA-neural network approach to evaluate branch efficiency of a large Canadian bank. Expert Systems with Applications, 31(1), 108-115. http://dx.doi.org/10.1016/j.eswa.2005.09.034

Yue, P. (1992). Data envelopment analysis and commercial bank performance: A primer with applications to Missouri banks. Federal Reserve Bank of St. Louis Review, 74.

\section{Notes}

Note 1. Small banks are those banks that have less than average size (of sample banks) in terms of their total assets, while big banks have average or more than average size.

Note 2. Young banks are those banks that have less than average age (of sample banks) in terms of years of working in the Egyptian banking market, while big banks have average or more than average age.

\section{Copyrights}

Copyright for this article is retained by the author(s), with first publication rights granted to the journal.

This is an open-access article distributed under the terms and conditions of the Creative Commons Attribution license (http://creativecommons.org/licenses/by/3.0/). 